\title{
Strength and Durability Aspects of Developed Microbial Concrete
}

\author{
Harsha Babu $E^{1}$, \\ ${ }^{1}$ Post Graduation Student \\ Department of civil engineering, \\ Sri Krishna College of Technology, \\ Tamil Nadu, India
}

\author{
Dr. I. Padmanaban ${ }^{2}$, S. Nithila ${ }^{3}$,G. Ezhilarasan ${ }^{4}$ \\ ${ }^{2}$ Head of the Department, ${ }^{3}$ Assistant Professor, \\ ${ }^{4}$ Post Graduation Student \\ Department Of Civil Engineering, \\ Sri Krishna College of Technology, Tamil Nadu, India
}

\begin{abstract}
A sturdy cement is one that performs agreeably under expected presentation conditions for determined existence of the structure. Strength and administration life are significant contemplations in solid structures subject to forceful condition. Run of the mill business ventures require durable toughness which is a steady objective of designers, contractual workers, planners and solid maker around the world. Concrete has an extreme burden bearing limit under pressure however the material is feeble in strain. Thus, it splits under stacking. Break in concrete happens because of physical and substance ecological assault that invigorates the weakening of inserted steel bars, which influences the sturdiness of cement and diminishes the life of structure. The fundamental focal point of this paper is to inspect the Probability of getting quality of cement by microbiologically actuated exceptional filler with the blend of counterfeit elements of cement. In this examination, a Bacillus bacterium (Bacillus subtilis) has been utilized to actuate CaCO3 precipitation. This marvel is called Microbiologically Induced Calcite Precipitation (MICP). This project presents to evaluate the influence of Bacillus Subtilis along with granite as coarse aggregate and Artificial fine aggregate and also its selfhealing properties is evaluated by health monitoring technique to check the quality of concrete.
\end{abstract}

Keywords- Bacillus Subtilis, Compressive and Split tensile Strength, UPV Test

\section{INTRODUCTION}

Concrete is one of the most important construction material. Concrete compresses of various raw materials ( cement, fine aggregate, coarse aggregate, granite chips, water) in different proportions to attain its required strength as a homogeneous mixture. Here granite chips are used as partial replacement of coarse aggregate to increase the toughness of concrete. Concrete have certain boundaries in its character such as, it is week in tension, it have limited ductility, crack formation is one of the major problem in concrete. The main aim is to make high durable concrete by reducing the crack caused by self weight as well as crack formed after loading. The concept of bacterial concrete is introduced to seal the cracks in the concrete by incorporating the mineral producing bacteria with metabolize crystal. This bacteria is used with water at different concentration in concrete to seal the cracks. This process is called as microbiological induced calcite precipitation. This is one of the best alternative and environmental friendly method to increase the durability of concrete.

\section{MATERIALS}

\section{A. Cement}

Normal PPC of grade53 is used in this project. Different kind of tests on property of cement is done as per IS 4031-1998. The specific gravity of the cement used in this project is 3.2.

\section{B. Coarse aggregate}

Coarse aggregate of size $20 \mathrm{~mm}$ is used here. As per IS 383 1970 all the basic test required to determine the character(ie. Water obsorption,crushing value, impact test) of the coarse aggregate is done.

\section{Granite chips}

Granite chips is a waste product that obtained during the manufacturing process of granite. They are obtained in abnormal shape and sizes, it should be grained and passed through $20 \mathrm{~mm}$ sieve and retain on $4.75 \mathrm{~mm}$. The retaining granite chips are used as alternate to coarse aggregate upto $30 \%$.

\section{D. $M-$ Sand}

Manufactured sand (M-Sand) is used as a substitute for river sand. They are produced by crushing hard granite rocks into fine powder and used as fine aggregate. In this project well processed M-sand is used as fine aggregate.

\section{E. Potable water}

Water is the key ingredient, which when mixed with cement,it forms heat of hydration reaction that helps to bind all the materials in concrete. Portable water confirming to the requirements of IS: 456-2000 was used for casting and curing.

\section{F. Bacillus subtilis}

Bacillus subtilis, Bacillus subtilis, it is a Gram-positive bacteria and non pathogenic bacteria. They are basically live in vegetative soil at a temperature between 25-35 degree celcius. It is a spore forming bacteria which secretes antibiotic during the process of spore formation for their healthy living and survival. Bacillus subtilis is brought up in its log phase in concreting site in liquid or aqueous state. This stage is having bacterial concentration 106 cells $/ \mathrm{ml}$. They are mixed along with the water used in concrete. 


\section{CULTIVATION OF BACTERIA}

Bacillus subtilis was prepared from soil sample. It is maintained in a nutrient agar solution. Serial dilution and plate count test is done for determining the identification and concentration of bacteria present. This technique is utilized to isolate the organisms, in the event that it is available in huge number in the blend. At whatever point required a single colony of the culture is inoculated into nutrient broth of $100 \mathrm{ml}$ in $250 \mathrm{ml}$ conical flask and the growth conditions are maintained at $370 \mathrm{C}$ temperature and placed in $140 \mathrm{rpm}$ orbital shaker.

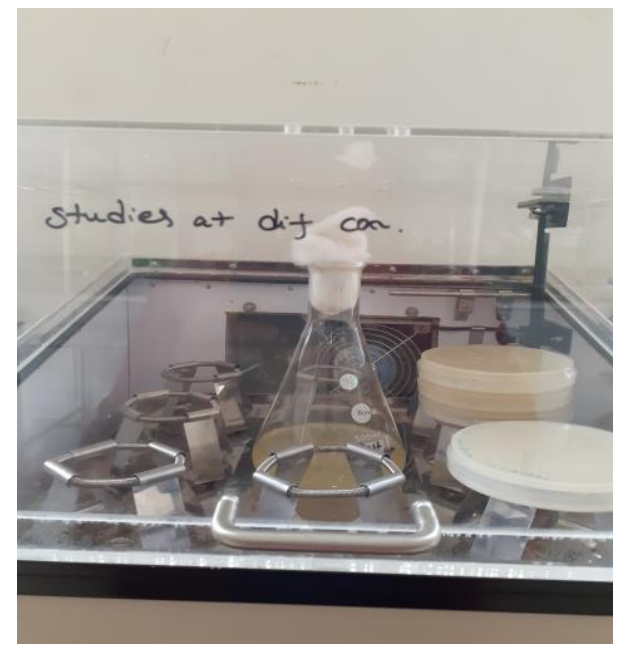

Fig- 1: Cultivation of bacteria

\section{MIX DESIGN}

Mix design is done to achieve the target mean strength and using of materials with required proportion as per the Indian standard codel provisions. The compressive strength of concrete is determined by cubes of size $150 \mathrm{~mm} \times 150 \mathrm{mmx} 150 \mathrm{~mm}$. Split tensile strength of the concrete was obtained by the cylinder of size $150 \mathrm{~mm}$ diameter and $300 \mathrm{~mm}$ height. In our investigation we've made M30 concrete.

Table- 1: Mix proportion

\begin{tabular}{|l|l|l|l|}
\hline Materials & Cement & Sand & $\begin{array}{l}\text { Coarse } \\
\text { aggregate }\end{array}$ \\
\hline Quantity $\left(\mathrm{kg} / \mathrm{m}^{3}\right)$ & 438.2 & 608 & 1160 \\
\hline Ratio & 1 & 1.38 & 2.65 \\
\hline
\end{tabular}

Table- 2: Percentage Of Replacement Of Granite Chips

\begin{tabular}{|c|c|c|}
\hline $\begin{array}{c}\text { Percentage of } \\
\text { granite chips } \\
\text { replacement }\end{array}$ & $\begin{array}{c}\text { Nominal coarse } \\
\text { aggregate }\end{array}$ & Granite chips \\
\hline $30 \%$ & 816 & 343 \\
\hline
\end{tabular}

\section{EXEPERIMENTAL TESTS}

\section{A. Compressive strength test}

After casting of cubes as per the mix design. The cubes are cured for 28 days to reach their maximum strength. After the curing process the cubes are dried for 24 hours in room temperature for compression test. After the drying process the cube is tested in compression testing machine. Before placing the cube the surface of the machine should be cleaned there should not be any obstruction. Then the cube is placed and the load gradually applied without shock and continuously at the rate of $5.2 \mathrm{KN} / \mathrm{sec}$ till the specimen fails. The maximum load recorded and any unusual features in the type of failure noted down. It is carried out for both 7 days and 28 days specimen.

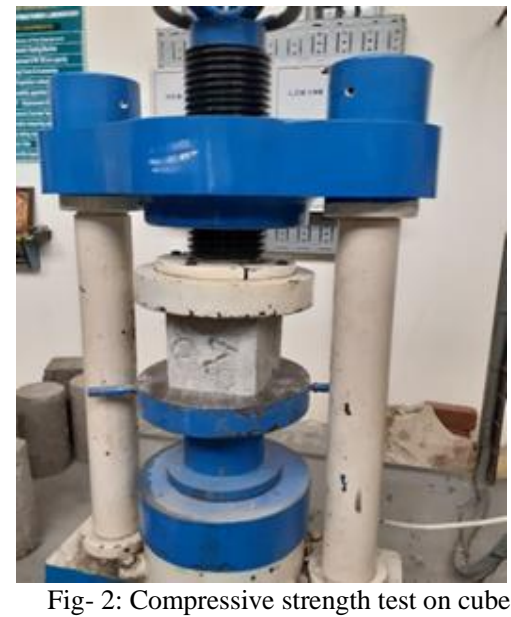

\section{B. Split tensile strength test}

Splitting tensile strength is done to evaluate tensile strength of the respective grade of concrete. For split tensile test cylinder specimen of size having height of $100 \mathrm{~mm}$ and diameter of $150 \mathrm{~mm}$ is casted as per the mix design and cured for 28days. After the curing process it is dried for $24 \mathrm{hrs}$ and tested. Before placing the cylinder specimen in the machine surface two steel plate is placed at top and bottom surface of the cylinder specimen as shown in fig3 for uniform distribution of load on the surface of the cylinder. the Split tensile strength tests are carried out at 7 and 28 days for the cylindrical specimen using compressive testing machine of $2000 \mathrm{kN}$ according to IS:516-1959. The load is applied slowly till the specimens split and readings are noted.

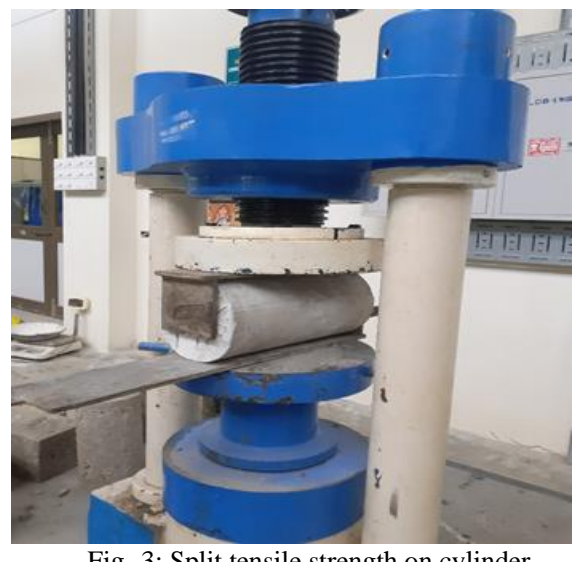

Fig- 3: Split tensile strength on cylinder

\section{Ultrasonic pulse velocity test}

This method consists of producing an ultrasonic longitudinal pulse by an electro acoustical transducer which is in contact with one surface of freshly placed concrete member under investigation. After the traversing is done at known distance in the concrete, pulse to be measured from which the pulse 
pulse velocity is calculated by calculating the transist time of the pulse from the time circuit. This procedure is called the "Ultrasonic method." Ultrasonic pulse velocity test is generally done to determine the presence of voids in the internal structure of concrete by means of passing the ultrasonic rays through the body on concrete and also to know the denseness of the concrete structure. All the respective bacterial concrete samples viz. conventional, $10 \mathrm{ml}$ $15 \mathrm{ml}, 20 \mathrm{ml}, 25 \mathrm{ml}, 30 \mathrm{ml}$ were tested.

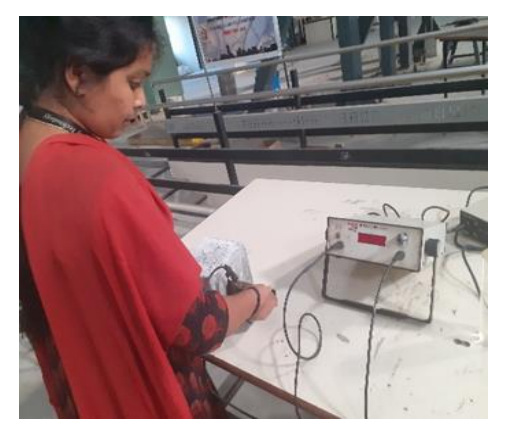

Fig- 4: UPV Test on cube

VI. RESULTS

A. Compressive strength test

Table-3: Compressive Strengtth of Bacterial Concrete

\begin{tabular}{|c|c|c|}
\hline $\begin{array}{c}\text { Bacterial solution } \\
\text { added(ml) }\end{array}$ & 7 days(MPa) & 28 days(MPa) \\
\hline 10 & 31.11 & 33.33 \\
\hline 15 & 31.07 & 33.71 \\
\hline 20 & 31.38 & 35.24 \\
\hline 25 & 31.5 & 35.55 \\
\hline 30 & 32.1 & 36.02 \\
\hline
\end{tabular}

Table-4: Compressive Strengtth of Conventional Concrete

\begin{tabular}{|c|c|}
\hline Conventional concrete & Compressive strength(MPa) \\
\hline 7 days & 23.8 \\
\hline 28 days & 28.6 \\
\hline
\end{tabular}

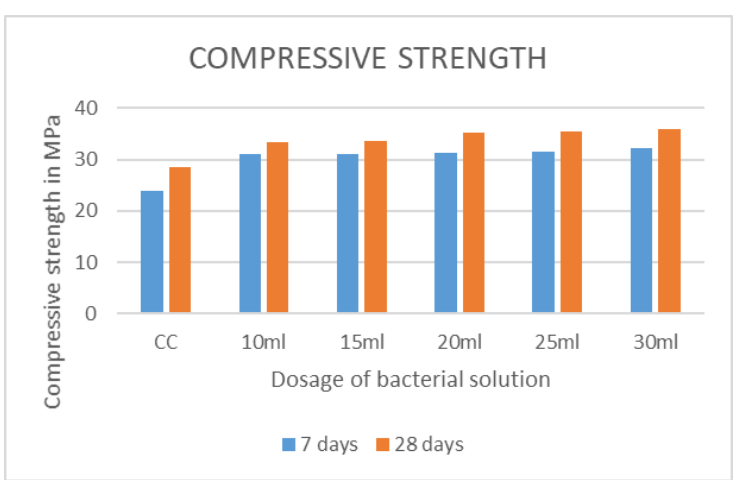

Fig-5: Compressive Strength Result

\section{B. Split tensile strength test}

Table-5: Split Tensile Strength of Conventional Concrete

\begin{tabular}{|c|c|c|}
\hline $\begin{array}{c}\text { Bacterial solution } \\
\text { added(ml) }\end{array}$ & 7 days(MPa) & 28 days(MPa) \\
\hline 10 & 1.06 & 1.69 \\
\hline 15 & 1.27 & 1.72 \\
\hline 20 & 1.48 & 1.84 \\
\hline 25 & 1.63 & 1.86 \\
\hline 30 & 1.92 & 2.2 \\
\hline
\end{tabular}

Table-6: Split Tensile Strengtth of Conventional Concrete

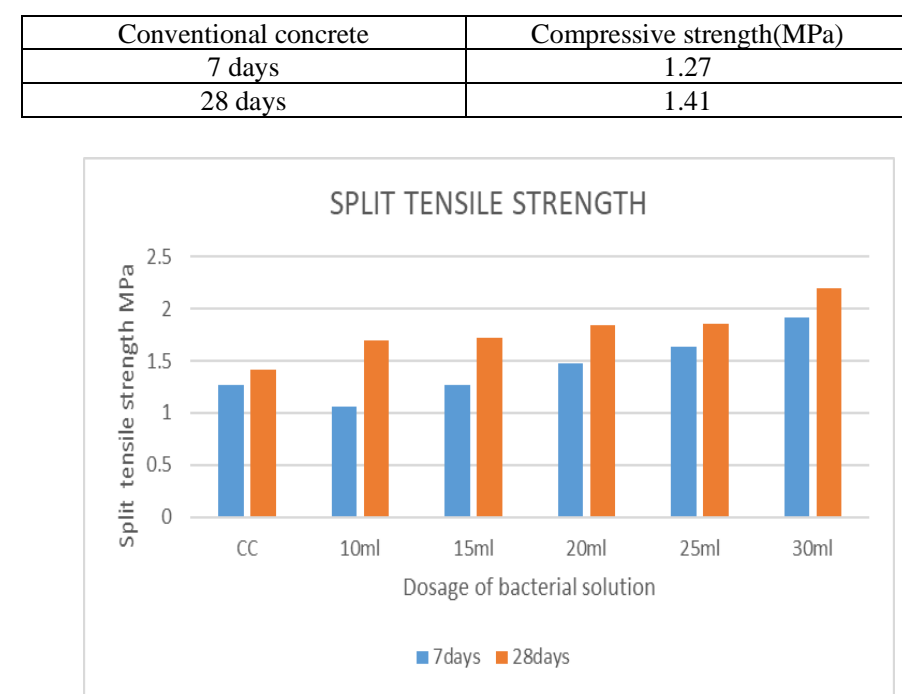

Fig-6: Split Tensile Strength Result

C. Ultrasonic pulse velocity test

Table VII Ultrasonic Pulse Velocity Test

\begin{tabular}{|c|c|c|c|c|c|}
\hline $\begin{array}{c}\text { Property of } \\
\text { concrete }\end{array}$ & $\begin{array}{c}\text { RCC } \\
\text { member }\end{array}$ & $\begin{array}{c}\text { Prob } \\
\text { distance }\end{array}$ & $\begin{array}{c}\text { Time } \\
(\text { micro } \\
\text { sec })\end{array}$ & $\begin{array}{c}\text { Velocity } \\
(\mathrm{km} / \mathrm{sec})\end{array}$ & $\begin{array}{c}\text { Probing } \\
\text { method }\end{array}$ \\
\hline $\begin{array}{c}\text { Conv. } \\
\text { concrete }\end{array}$ & Cube & 150 & 28.8 & 5.2 & Direct \\
\hline $\begin{array}{c}\text { Bacteria } \\
\text { concrete }\end{array}$ & & & & & \\
\hline $10 \mathrm{ml}$ & Cube & 150 & 28.2 & 5.3 & Direct \\
\hline $15 \mathrm{ml}$ & Cube & 150 & 27 & 5.5 & Direct \\
\hline $20 \mathrm{ml}$ & Cube & 150 & 25.6 & 5.85 & Direct \\
\hline $25 \mathrm{ml}$ & Cube & 150 & 26.2 & 5.75 & Direct \\
\hline $30 \mathrm{ml}$ & cube & 150 & 25.2 & 5.88 & Direct \\
\hline
\end{tabular}

\section{CONCLUSION}

Based on the investigation and results presented in this paper, the following conclusions are reached:

- The compressive and split tensile of M30 microbial concrete is found to be higher than $\mathrm{M} 3 \mathrm{O}$ conventional concrete.

- The compressive strength of concrete after 28 days using Bacillus Subtilis has been increased upto $26 \%$ compared to conventional concrete.

- The split tensile strength of concrete using Bacillus Subtilis has been increased upto $56 \%$ compared to conventional concrete.

- Ultrasonic Pulse Velocity test that is conducted on the bacterial concrete specimen shows that the value of ultrasonic pulse velocity is increased due to enriched pore and micro structure. The values obtained are above $4.5 \mathrm{~km} / \mathrm{sec}$ which shows excellence of strength of the concrete.

\section{REFERENCES}

[1] Granger S, Loukili A, Pijaudier-Cabot G, Chanvillard G. "Experimental characterization of the self-healing of cracks in an ultra high performance cementitious material: mechanical tests and acoustic emission analysis". Cem Concr Res 2007;37:519-27.

[2] G.Adithya Vijay,R Tamilarasan, "Experemental investigation on self healing concrete using E-Coli bacteria",International journal of trend and development. 
[3] Erik Schlangen, Senot Sangadii, “Addressing infrastructure durability and sustainability by self healing mechanism"Elsveir 2013

[4] A.Gandhimathi,N.Vigneswari,S.M.Janani, "Experimental study on self healing concrete",Emerging trends in engineering research,2012.

[5] Henk M Jonkers,Arian Thussen, "Application of bacteria as self healing agent for the development of sustainable concrete,Elseveir,December-2008

[6] H.M.Jonkers, "Bacteria based self healing concrete", Heron-2011

[7] Koustubh.A Joshi,Madhav B Kumthekar,Vishal P Godake "Study of self healing mechanism and its impact on bacillus bacteria impregnated concrete",International research journal of engineering and technology ,June -2016 volume - 3

[8] Kusuma K,Amit Kumar Rai,Prashant Kumar, "Self healing concrete" International jouranal pf engineering and technology,May-2018 volume-5.
[9] S.S.Bang,.Ramakrishnan "Microbiologically-enhanced crack remediation (MECR)", the International Symposium on Industrial Application of Microbial Genomes, Taegu, Korea, 2001.

[10] Stocks-Fischer, S.; Galinat, J. K.; and Bang, S. S., "Microbiological Precipitation of CaCO3," Soil Biology \& Biochemistry, V. 31, No. 11, 1999, pp. 1563-1571.

[11] Nemati M, Voordouw G. "Modification of porous media permeability, using calcium carbonate produced enzymatically in situ". Enzyme Microb Technol 2003;33(5):635- 42

[12] Hearn N. "Self-sealing, autogenous healing and continued hydration: what is the difference?" Mater Struct 1998;31:563-7. 